\title{
PERFORMANCE COMPARISON OF REAL ESTATE INVESTMENT TRUST SECTOR AND VENTURE CAPITAL INVESTMENT TRUST SECTOR IN TURKEY
}

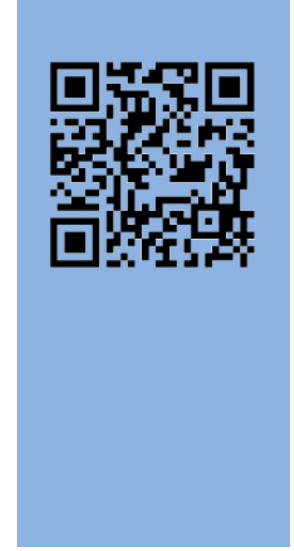

Metin AKTAŞ

Zabiullah DARWISH ${ }^{2}$

\begin{tabular}{|c|c|}
\hline $\begin{array}{l}\text { ARTICLE } \\
\text { INFORMATION }\end{array}$ & ABSTRACT \\
\hline $\begin{array}{l}\text { Submission Date } \\
\text { Accepted Date }\end{array} \begin{array}{l}: 14 / 11 / 12020 \\
\\
\text { Keywords: } \\
\text { Real Estate, Venture Capital, } \\
\text { Performance } \\
\\
\text { JEL Codes: } \\
\text { L85, G24, L25 }\end{array}$ & $\begin{array}{l}\text { The aim of this study is to compare performance of the real estate } \\
\text { investment trust (REIT) sector and venture capital investment trusts } \\
\text { (VCIT) sector in Turkey. In order to accomplish this purpose, Data } \\
\text { Enveloped Analysis is utilized by using the data of } 32 \text { REIT and } 7 \text { VCIT } \\
\text { for the yearly term of 2014-2019. In addition, while net profit amount } \\
\text { and profit per share are used as output variables, risky investment } \\
\text { amount, total equity amount, total asset amount are used as input } \\
\text { variables. At the end of the analysis, in general it is concluded that the } \\
\text { real estate investment trust sector hashigher efficiency than venture } \\
\text { capital investment trust sector has. Besides, according to the Malmquist } \\
\text { Productivity results, again real estate investment trust sector has more } \\
\text { productivity than the venture capital investment trust sector has. }\end{array}$ \\
\hline MAKALE BİLGİSİ & $\ddot{O ̈ Z}$ \\
\hline $\begin{array}{l}\text { Makale Geliş Tarihi : } 14 / 11 / 2020 \\
\text { Makale Kabul Tarihi : 11/12/2020 } \\
\\
\text { Anahtar Kelimeler: } \\
\text { Gayrimenkul, Girişim } \\
\text { Sermayesi, Performans } \\
\text { JEL Kodları: } \\
\text { L85, G24, L25 }\end{array}$ & $\begin{array}{l}\text { Bu çalışmanın amacı, Türkiye'de Gayrimenkul Yatırım Oraklığı sektörü } \\
\text { ile Girişim Sermayesi Yatırım Ortaklığı sektörünün performansların1 } \\
\text { karşılaşırmaktır. Bu amaç doğrultusunda, 2014-2019 dönemine ait } 32 \\
\text { tane gayrimenkul yatırım ortaklığının ve } 7 \text { tane girişim sermayesi } \\
\text { yatırım ortaklığının yıllık verileri kullanılarak, Veri Zarflama yöntemi } \\
\text { ile analiz yapılmaktadır. Veri Zarlama analizinde, net kar tutarı ve hisse } \\
\text { başına kar tutarı, çıktı değişkenleri olarak kullanılırken, riskli yatırım } \\
\text { tutarı, toplam öz sermaye tutarı ve toplam aktif tutarı, girdi değişkenleri } \\
\text { olarak kullanılmaktadır. Yapılan analiz sonucunda, genel olarak, } \\
\text { gayrimenkul yatırım ortaklığı sektörünün, girişim sermayesi yatırım } \\
\text { ortaklı̆̆ı sektörüne göre daha etkin olduğu, Malmquist verimlilik } \\
\text { sonuçlarına göre de, gayrimenkul yatırım ortakllı̆ı sektörünün, girişim } \\
\text { sermayesi yatırım ortaklığı sektörüne göre daha verimli olduğu } \\
\text { anlaşılmaktadır. }\end{array}$ \\
\hline
\end{tabular}

${ }^{1}$ Prof. Dr., Niğde Ömer Halisdemir University, Faculty of Economics and Administrative Sciences, Department of Business Administration, Division of Finance, ORCID ID: 0000-0003-4366-868, maktas@ohu.edu.tr

${ }^{2}$ PhD Student, Niğde Ömer Halisdemir University, Graduate School of Social Science, Department of Business Administration, Division of Finance, ORCID ID: 0000-0001-8855-9738, zabi.darwish321@gmail.com 


\section{Introduction}

Real Estate Investment Trusts, in general terms, are the institutions that hold, operate or finance real estate in their portfolios. Although they are subject to different establishment conditions, and legislative provisions in each country, their main purpose is to bring small saving owners together, and invest in large real estate projects. In this way, they also find solutions to the financing problem for large projects, and benefit from many tax advantages offered to them.

In addition, in today's economy, where globalization is continuing rapidly, the most important problems for individuals and institutions to realize new ideas are the lack of finance. One of the alternative financing techniques developed to solve this problem is venture capital investment trusts. These institutions aim to add value to companies and to earn investors by making long-term investments in companies with high competition and growth potential. In this way, it is aimed to implement promising projects, reduce unemployment and contribute to the national economy. Venture capital financing method has emerged to solve the financing, and management problems of small and medium size companies, which are the locomotives of the economy.

The main characteristics of the venture capital financing method consist of high risk, high profit, and high technology. Venture capital is a type of financial investment with low probability of very high profit and high probability of low loss. Venture capitalists are usually active investors and they are also capable of providing technical and managerial support to the investmentsfor the fields of finance, marketing, personnel and planning.

Entrepreneurs are discovering new investment opportunities from all over the world and the benefit of these investment opportunities can only be obtained by finding right investors and convincing them. It is only possible to find the right investorsand acquire financing under suitable conditionsif the entrepreneur and the investor are fully aware of each other.

Since these mentioned real estate and venture capital investment trusts are very important for the economy in terms of supporting production and reducing unemployment, it is important to conduct research on them. Besides both the real estate and venture capital investment trusts are high-risk financing models, the risk levels of the real estate and venture capital investment trusts differ according to the risk status of their investments. Therefore, this study is also important in terms of providing information to investors about which real estate and venture capital investment trusts sector will be suitable for investors according to their risk preferences. 
In this study, real estate investment trust sector and venture capital investment trustsector in Turkey are compared based ontheir performance. In the study, Data Enveloped Analysis method is used, net profit amount and profit per share amount are used as output variables, risky investment amount, total equity amount and total asset amount are used as input variables.

\section{Literature Review}

Han and Liang (1995) evaluated the long term (1970-1993) performance of real estate investment trusts by using a specific performance measure, the Jensen index. They indicated that REIT performance was similar to three-month Treasury bills and a stock market portfolio (S\&P 500 index). They also investigated that equity REITs performed much better than mortgage REITs.

Çitak (2008) conducted a research under the title of a nonparametric Data Enveloped Analysis (DEA) to evaluate the effectiveness of investment trusts in Turkey. As a result of the annual analysis, which included three input variables, and three output variables in the study by covering the period of 2005-2007, it was revealed that the activity inefficiencies of the securities investment partnerships due to the scale's inefficiency rather than pure technical ineffectiveness. They have become more effective by increasing their scale effectiveness recently. It is also stated that they can become more effective by expanding. It is concluded that large securities investment trusts are more effective than small securities investment trusts.

Kiyilar and Hepsen (2010) performed an analysison performance appraisal of real estate investment trusts indexed in Istanbul Stock Exchange. The used data of the analysis was composed of 8 REITs during the period of January 2000 and December 2008. In the analysis, the Sharpe Index and the Jensen Index were used to measure the performance of each REIT relative to the market portfolio. At the end of the analysis, the results show that Pera REIT performed better than the other REIT stocks for both Sharpe and Jensen Indices over the period.

Aytekin and Kahraman (2015) aimed to measure the financial activities of companies traded in the Istanbul Stock Exchange Real Estate Investment Trusts Index with Data Envelopment Analysis. In the analysis, the financial ratios of the companies in the index for the 5-year period covering 2008-2012 are used. In the model, which was established with three input and three output variables, the efficiency values of different number of companies in the index were calculated over the years. In the study, general administrative expenses, financing expenses, and paid capitals were used as input variables of REITs. On the other hand, net asset value, net profit, and market value were used as output variables. 
Rençber and Akbulut (2017) compared the efficiency and performance of VCIT companies traded on Istanbul Stock Exchange (ISE). In the study, by using data envelopment analysis model and data of 11 VCIT companies for the yearly term of 20112016, efficiency and productivity levels of the companies were compared. In data envelopment analysis application, while current rate, borrowing rate and cash rate are used as input variables, equity profitability, net profit margin and active turnover rate are used as output variables

Aktaş and Avcı (2017) performed an analysis to compare performance of participation banking systems in some countries during the years of 2011-2015. In the analysis, they applied data of Malaysia, Saudi Arabia, Katar, Kuwait, Iranian, United Arap Emirates and Turkey. In their studies, they also used data Enveloped Analysis and Panel Data Analysis as methods. While collected funds, fixed assets, equity capital and personal removals were used for input variables, funds provided and the other active assets were used as output variables in the Data Enveloped Analysis. They also used effectiveness scores obtained from the Data Enveloped Analysis as dependent variable and asset profitability ratio, equity profitability ratio, loan deposit ratio and debt ratio as independent variables for the Panel Data Analysis.

Sirma (2019) aimed to investigate whether the shares of REITs were affected more by company assets or by the market. In his study, the effect of the increase in the assets of REITs traded between 2007 and 2017 on stock returns was analysed. The analysis was done with a panel data method. At the end of the analysis, it is concluded that the increase in the assets of REITs is not as effective as the factors affecting the whole market.

Aktaş and İlgün (2019) comparedthe performance of the venture capital investment trusts (VCIT) in Turkey. In order to get this goal, data enveloped analysis was performed by using data of seven VCIT for the yearly term 2012-2017. In the analysis, while equity profitability ratio and market value/book value ratio were used as output variables, venture capital investment ratio, security investment ratio and equity ratio were used as input variables.

Aktaş and Darwish (2020) compared financial performance of real estate investment trust sector and venture capital investment trust sector operating in Turkey. They also intended to determine especially if the sectors are complying with their risk and return features. In order to conduct this study, ratio analysis method was applied. Annual investment, profitability, capital structure, and stock market ratios of 32 REITs and 7 VCITs companies for the period of 2014-2019 were used as data. 


\section{Methodology and Data}

In 1978, Charnes, Cooper and Rhodes (CCR) developed a mathematical programming formulation based on the amount of input and output observed for a group of similar decision-making units and called this approach Data Envelopment Analysis (DEA). The CCR model which can evaluate relative efficiency with multiple inputs and multiple outputs was developed based on Farrel (1957) single input-single output technical effectiveness measurement (Mecid, 2012: 1).

As Ji and Lee (2010) stated that DEA allows multiple inputs-outputs to be considered at the same time without any assumption on data distribution. In each case, efficiency is calculated as a proportional change in inputs or outputs. A DEA model can be subdivided into an input-oriented model, which minimizes inputs while satisfying at least the given output levels, and an output-oriented model, which maximizes outputs without requiring more of any observed input values.

DEA method evaluates the decision making units without the need for a functional structure, in other words, it distinguishes effective decision making units from ineffective decision making units and determines the source and amount of ineffective decision making units (Sar1, 2015: 21)

According to Huguenin (2012, firm efficiency is defined as the ratio of the sum of its weighted outputs to the sum of its weighted inputs and DEA is appropriate for the use of both private sector companies and public sector organizations (and even for entities such as regions, countries, etc.).

As Kök and Deliktaş (2003) stated, the feature of data envelopment analysis technique is that it has developed a reference (production limits curve) criterion. Thus, this reference technology levels for each input and output variable are defined by the linear component of each input and output observed simultaneously. More importantly, the data envelopment analysis does not require any assumptions about the functional structure.

Data Envelopment Analysis is defined as an indicator that represents the nonparametric linear programming approach, excluding input and output prices. DEA does not take into account the error, which is a disadvantage of this indicator. Effectiveness measures start from 0 , full activity up to 1 cannot be mentioned and number 1 indicates the maximum effectiveness level. DEA is a linear programming model and nonparametric mathematical programming model to estimate production limits by comparing inputs with outputs. Simply, DEA represents the portion of weighted outputs to weighted inputs and more obtained output indicatesmore effective units (Alharthi, 2016: 75-76). 
As Gedik (2011) stated, DEAis a linear programming-based measurement technique that includes many inputs and many outputs. This is used to measure the relative activities of decision units with each other in production situations where these inputs and outputs cannot be expressed as a single input or a single output.

As Pehlivan (2009) stated, DEA can be used in two ways for input and output. First, Input-Enveloped Analysis Models investigate what should be the most appropriate input combination that can be used to produce a particular output composition in the most efficient way. Second, Output-Envelope Analysis Models focus on how many output combinations can be obtained with a given input combination. Data envelopment analysis measures the relative effectiveness of a producer unit as the ratio of total weighted output to total weighted input.

According to Özkaya (2017), DEA measures the relative effectiveness of decision making units with multiple inputs and outputs by minimizing inputs or maximizing outputs. It evaluates its technical activities by considering the inputs and outputs of similar economic units that are generally in the same field of activity. In case of only one input and one output the efficiency of economic units is very easy to measure, but in multi-input and multi-output systems, the measurement of effectiveness can only be calculated using linear programming techniques.

In this study, Data Envelopment Analysis was performed by using 3 input variables and 2 output variables of thereal estate investment trust sector which includes 30 companies and venture capital investment trust sector which includes 7 companies during the 2014-2019 yearly terms. Explanation of the input and output variables used in the analysis take place in Table 1 below.

Table 1.Input and Output Variables Used in the Study

\begin{tabular}{|c|c|}
\hline Output Variables & Explanation \\
\hline Net Profit Amount & Net Profit / Stock Number \\
\hline Profit Per Share & \\
\hline Input Variables & $\begin{array}{c}\text { Venture Capital Investment Amount } \\
\text { Real Estate Investment Amount }\end{array}$ \\
\hline Risky Investment Amount & \\
\hline Total Equity Amount & \\
\hline Total Asset Amount & \\
\hline
\end{tabular}

The ratios used in the analysis are calculated by us based on the data obtained from the publicly disclosed financial statements of both real estate and venture capital investment trusts from the web site of Istanbul Stock Exchange and Is Yatirim. 


\section{Analysis}

In this study, performance comparison of the real estate investment trust sector and venture capital investment trust sector in Turkey was performed by the Data Envelopment Analysis method. It is aimed to compare their efficiency and productivity.

\subsection{Efficiency Analysis}

The efficiency results of real estate investment trust sector and venture capital investment trust sector for the years of 2014-2019 are shown in the Graph -1 below.

That the efficiency values of the real estate investment trust sector and venture capital investment trust sector used in the study are 1 mean that they are effective in terms of total efficiency. When they move away from the value of 1 , their efficiency decrease.

Graph -1 below shows the efficiency values of real estate investment trust sector andventure capital investment trust sector for the years of 2014-2019. As it is seen, both real estate investment trust sector and venture capital investment trust sector have 1 efficiency value in years of 2014, 2015 and 2019. This means that both of the sectors are efficient in these years. The efficiency of venture capital sector is less than the efficiency of real estate sector in 2016 and 2018, but more in the 2017. Therefore, it can be concluded that overall, real estate sector is more efficient.

Graph 1. Scale Efficiency of Real Estate Sector and Venture Capital Sector

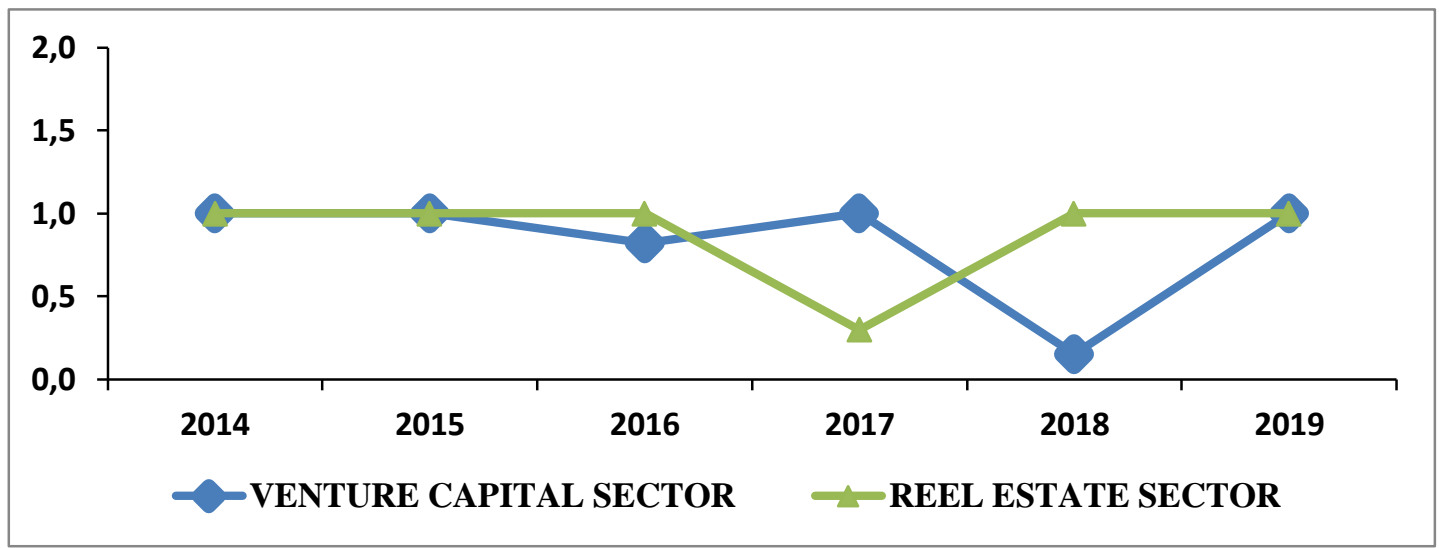

The effective and ineffective situations of the real estate investment trust sector and venture capital investment trust sector for the 2014-2019 period take place in the Table -2 below. It is seen from the table that the real estate investment trust sector is effective in all years except 2017 and the venture capital investment trust sector is effective in 2014, 2015, 2017 and 2019, bu it is not effective in 2016 and 2018. 
Table 2. Efficiency and Inefficiency Situation of Real Estate Investment Trust Sector and Venture Capital Investment Trust Sector

\begin{tabular}{|l|c|c|c|c|c|c|}
\hline & $\mathbf{2 0 1 4}$ & $\mathbf{2 0 1 5}$ & $\mathbf{2 0 1 6}$ & $\mathbf{2 0 1 7}$ & $\mathbf{2 0 1 8}$ & $\mathbf{2 0 1 9}$ \\
\hline $\begin{array}{l}\text { Real Estate } \\
\text { Investment Trust } \\
\text { Sector }\end{array}$ & Effective & Effective & Effective & $\begin{array}{c}\text { Ineffectiv } \\
\text { e }\end{array}$ & Effective & Effective \\
\hline $\begin{array}{l}\text { Venture Capital } \\
\text { Investment Trust } \\
\text { Sector }\end{array}$ & Effective & Effective & $\begin{array}{c}\text { Ineffectiv } \\
\text { e }\end{array}$ & Effective & $\begin{array}{c}\text { Ineffectiv } \\
\text { e }\end{array}$ & Effective \\
\hline
\end{tabular}

\subsection{Malmquist Productivity Analysis}

When the productivity value of the real estate investment trust sector and venture capital investment trust sectorare higher than 1, it indicates that there is an increase in productivity, when it is less than 1 , it also indicates that there is a decrease in productivity, and a value ofproductivity equal to 1 indicates no change in productivity.

The productivity results of real estate investment trust sector and venture capital investment trust sector for the years of 2014-2019 take place in the Graph-2 below. It is seen from the graph that productivity values of real estate investment trust sectorare greater than productivity values of venture capital investment trust sector for the years of 2015, 2016 and 2018. On the other hand, productivity values of real estate investment trust sector are less than productivity values of venture capital investment trust sector for the years of 2017 and 2019. It can be concluded that overall, real estate investment sector is more productive and also more stable.

Graph 2. Malmquist Total Factor Productivity

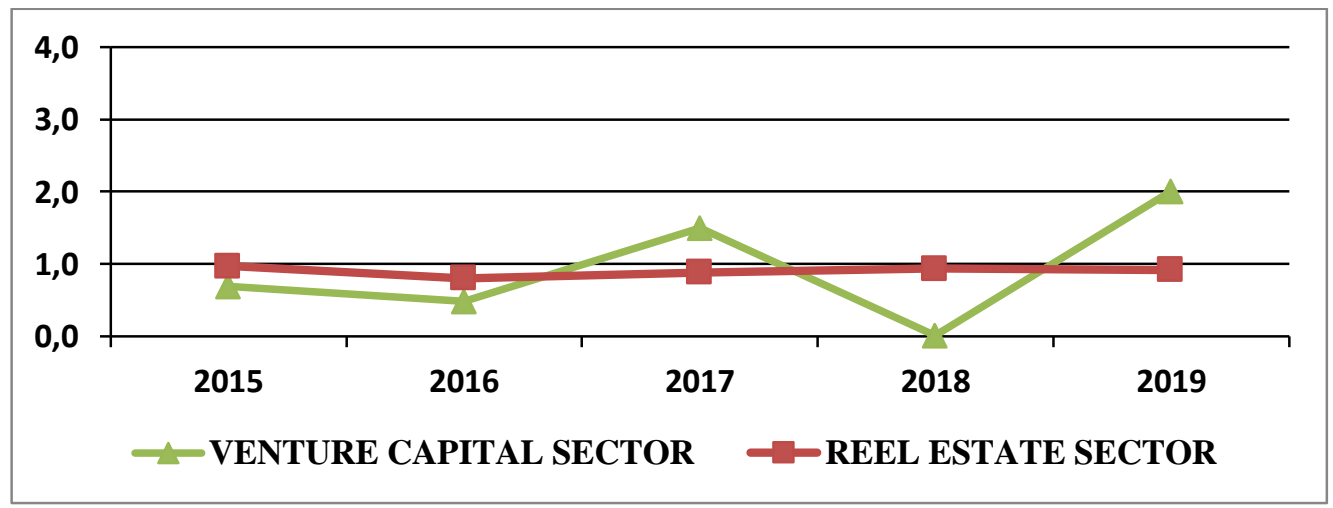

\section{Conclusion}

Since real estate and venture capital investment trusts are very important for an economy in terms of increasing production and reducing unemployment. Besides, both of the real estate investment trusts and venture capital investment trusts are high risky financing models. Therefore, it is important to conduct research on these sectors and this 
study is also important in terms of providing information to investors about real estate and venture capital investment trusts sectors.

In order to compare performance of real estate investment trust sector and venture capital investment trust sector, Data Enveloped Analysis was used with the data of 30 REIT companies and 7 VCIT companies for the years of 2014-2019. In addition, while net profit amount and profit per share were used as output variables, risky investment amount, total equity amount and total asset amount were used as input variables.

While evaluating the efficiency ranking of real estate investment trust and venture capital investment trusts, input and output variables used in data envelopment analysis should be taken into account. Since the efficiency ranking of the sectors was obtained according to the variables used in this study.

At the end of the data enveloped analysis, in general, it is found that real estate investment trust sector is more efficient than venture capital investment trust sector, in addition, according to the Malmquist Productivity Analysis, it is also found that in general, real estate investment trust sector is more productive than venture capital investment trust sector has.

Since naturally venture capital investment trust sector is more risky than real estate investment trust sector, it is expected that venture capital investment trust sector has more efficiency than real estate investment trust sector has. The opposite result achieved in this study implies that direct relation of risk and return may not occure in developing countries like Turkey.

\section{References}

Aktaş, M. and Avcı, T. (2017). Performance Comparison of the Participating Banking on a Country Basis, International Journal of Social Science Research, 6 (2), 66-82.

Aktaş, M. and İlgün, Y. (2019). Performance Comparison of the Venture Capital Investment Trusts in Turkey, International Journal of Social Science Research, 8(1), 73-92.

Aktaş, M. and Darwish, Z. (2020). Comparison of Reel Estate Investment Trusts and Venture Capital Investment Trusts in Turkey Based on Their Financial Ratios, International Journal of Social Science Research, 9 (1), 63-78.

Assani, S. and Assani, A. (2018). Overview of Data Envelopment Analysis (DEA), Presentation November, University of Science and Technology of China.

Aytekin, S. and Kahraman, E. (2015). The Evaluation of The Financial Efficiency of The Companies in BIST Real Estate Investment Trusts Index (XGMYO) by Data Envelopment Analysis, Niğde University Faculty of Economics and Administrative Sciences Journal, Vol-Number: 8 (1), 289301.

Çıtak, L. (2008). Evaluation of The Efficiencies of Securities Investment Trusts in Turkey by Data Envelopment Analysis, Erciyes University Faculty of Economics and Administrative Sciences Journal, sayı: 31, 69-94. 
Gedik, M. (2011). Tax Competition Efficiency Evaluation: Application of Data Envelopment Analysis for the OECD Countries, Finance Magazine, Say1:160, January - June.

Han, J. and Laing, Y. (1995). The Historical Performance of Real Estate Investment Trusts, Journal of Real Estate Research, 10 (3), 235-262.

Huguenin, J. M. (2012). Data Envelopment Analysis (DEA) A pedagogical guide for decision makers in the public sector, Institut de hautes etudes en administration publique Swiss Graduate School of Public Administration, IDHEAP, Lausanne.

Ji, Y. and Lee, C. (2010). Data Envelopment Analysis, The Stata Journal, 10 (2), 267-280.

Kiyilar, M. and Hepsen A. (2010). Performance Apprais a lof Real Estate Investment Trusts (REITs): A Practice in Istanbul Stock Exchange, Journal of Institute of Business, 21 (65), 11-23.

Kök, R. and Deliktaş, E. (2003). Endüstri İktisadında Verimlilik Ölçme ve Strateji Geliştirme Teknikleri, Dokuz Eylül Üniversitesi Yayınları, İzmir.

Mecid, E. D. (2012). Veri Zarflama Analizinde Homojen Ağırlıklandırma Üzerine Yeni Bir Yaklaşım, Unpublished $\mathrm{PhD}$ Thesis, Gazi University Institute of Science and Technology.

Rençber, Ö. F. and Akbulut, R. (2017). A Research on the Relationship Between Financial Indicators of Interest Capital Investment Partnerships, Karadeniz Technical University, XVIII. International Symposium on Econometrics, Operations Research and Statistics.

Sarı, Z. (2015). Panel Data Analysis and an Application, Unpublished Master Thesis, Hacettepe University Institute of Science and Technology.

Sirma, I. (2019). Effect of Real Estate Investment Trusts Portfolio Structure on the Market Performance, Alphanumeric Journal, 7 (1), 25-36. 